\title{
Anxiety in Writing Research Report among Graduate Students in Ignatius Ajuru University, Faculty of Education, Rivers State, Nigeria
}

\author{
Margaret G. Kennedy ${ }^{1}$, Elsie Williams ${ }^{2}$, Victoria Asodike ${ }^{3}$ \\ ${ }^{1}$ International Secondary School, Rivers State University, Port Harcourt, Nigeria \\ ${ }^{2}$ Sports Institute of Rivers State Isaka, Okirika, Nigeria \\ ${ }^{3}$ Department of Educational Foundation, Rivers State University, Port Harcourt, Nigeria \\ Email: *margaretkennedy240@gmail.com, adosieadosie@gmail.com, Vickyprest87@gmail.com
}

How to cite this paper: Kennedy, M. G., Williams, E., \& Asodike, V. (2020). Anxiety in Writing Research Report among Graduate Students in Ignatius Ajuru University, Faculty of Education, Rivers State, Nigeria. Open Journal of Social Sciences, 8, 127-140. https://doi.org/10.4236/jss.2020.811013

Received: October 4, 2020

Accepted: November 16, 2020

Published: November 19, 2020

Copyright $\odot 2020$ by author(s) and Scientific Research Publishing Inc. This work is licensed under the Creative Commons Attribution International License (CC BY 4.0).

http://creativecommons.org/licenses/by/4.0/

\begin{abstract}
Prevalence of anxiety in writing research report among graduate students in faculties of education in Nigeria, particularly Rivers State cannot be overemphasized; it has led to barriers in completing theses and dissertation. This is evident in the number of graduating students each year compared to the number admitted at the start of the programme. This study sought to investigate if there were indicators of the presence of anxiety in writing research report among graduate students. The study utilized the descriptive survey using a population of 392 graduate students for 2017/2018 academic session in all 5 departments of the faculty of education of Ignatius Ajuru University of Education (IAUE) Port Harcourt. Census sampling method was used to study the entire population. It is not certain if gender influences anxiety in writing research report. Thus the purpose of this study was to compare levels of anxiety in writing research report among male and female graduate students in IAUE one of the Universities in Rivers State. The outcome measure Research Writing Anxiety Rating Scale (RWARS) revealed that fear of library use and indifferent attitude of supervisors does not induce anxiety significantly but moderately among male and female graduate students but fear of statistics produced significant level of anxiety differently among male and female graduate students; female students were found to have higher levels of statistic anxiety than their male counterparts. Based on these finding it was recommended amongst others that lecturers with high level of competence and good teaching methods should be made to teach statistics at the graduate level.
\end{abstract}

\section{Keywords}

Anxiety, Graduate Students, Report, Research, Writing 


\section{Introduction}

Writing a research report is a partial fulfilment that must be met in the award of a certificate or degree in institutions of higher learning especially in institutes and faculties of education in Nigeria. This requirement has often caused anxiety among students. Some students after the successful completion of their course work abandon writing the research report; others employ the services of machineries to do this aspect for them; yet others go to other institutions of higher learning to plagiarise other peoples work; only the committed and dedicated one gives it all it takes to accomplish this task. Okoroma (2013) in agreement with this view says that many students have missed graduation and national youth service due to inability to write or finish research works on time.

Research is concerned with finding answers or solutions to questions raised about observed issues or phenomena or events in the environment through systematic and logical procedures (Nwankwo, 2013). Nwankwo believes that research does not occur in a vacuum rather a researcher must have observed an event, happening or a phenomenon in the environment which must have given him a concern or worry, based on this state of mind that the researcher is spurred or motivated to investigate probably, the why, what, how or the when of that observed event. Research writing has two basic approaches namely, qualitative and quantitative types. The quantitative type is statistic based while the qualitative type is description based; the quantitative type is the one encouraged in faculties of education in Nigeria. Research holds the key to the development of education in any country. Agbakwuru (2010) states the usefulness of research as follows:

- Knowledge creation/filling of gaps in knowledge.

- Successful adaptation of foreign developed philosophies and ideas to local circumstances.

- Evaluation of the effectiveness of policies and programmes in meeting to set goals and targets.

- Identifying the problems and constraints of society's present and future educational needs.

- Knowing certain conditions under which to predict the society's present and future educational, socio-economic and technological state.

- Selecting alternative path of remedial or useful options.

- Developing, controlling and directing the affairs of the society to desirable direction.

Anxiety has continued to interfere with research writing among students at all levels. Anxiety is an unpleasant state of mental uneasiness, nervousness, apprehension and obsession or concern about some uncertain events. Akinade (2001) defines "Anxiety" as exaggerated state of apprehension, uneasiness, distress or fear of an imminent danger that initiates a set of behaviour such as some defence mechanisms.

Onwuegbuzie (1997) in his pioneer study on research anxiety conjectured that 
research anxiety is multidimensional mechanism which includes library anxiety, statistical anxiety, composition anxiety and research process anxiety. The role of the library is to support the students' information needs by providing them relevant resources and services (Onwuegbuzie, 2004). At some point students will find it necessary to use the library but this is a problem for some students who feel that they do not have the skills and experience in using and finding their way around their resource which the library provides (Onwuegbuzie, 2013).

This study will examine library anxiety, statistics anxiety and supervisor's indifferent attitude to determine how they influence research anxiety among graduate students in Ignatius Ajuru University of Education. Library anxiety has been identified as one of the contributory factors to research anxiety by previous researchers. McPherson (2015) revealed that $50 \%$ of library users experience some form of anxiety based on how they described their feelings as either confused (51.3\%); uncertain (49.3\%); or anxious (32.6\%). McPherson (2015) reported that the initial feelings of anxiety about the library appeared to have affected them negatively; $40 \%$ of the students stated that it affected their ability to complete their assignments with as many as $20 \%$ citing failure to turn in a good assignment and the other $26 \%$ having to delay the completion of same due to library anxiety. Other initial feelings were reported by $37 \%$, some of which included developing a phobia for the library, having to go elsewhere to conduct their research and becoming discouraged from using the library unless it was absolutely necessary.

$\mathrm{Lu}$ and Adkins (2018) investigated library anxiety among 15 international graduate students in the United States. Findings from the pilot study shows that mechanical barriers were the smallest sources of library anxiety and affective and staff barriers were the greatest sources of library anxiety. No significant gender or disciplinary difference was found in terms of the level of library anxiety among international students.

The indifferent attitude of some supervisor's towards supervision of students research work was also identified by researchers as a major cause of anxiety in research writing; Maharajan, Rajiah, Tam, Chaw, Ang and Young (2017) investigated pharmacy students anxiety towards research during their undergraduate degree, how to reduce it? In a cross-sectional study conducted among final year student of pharmacy using a convenient sampling method, participants involved 128 students from a population of 149 . Results revealed that $91.4 \%$ of the student felt that they were doing very badly during their data analysis or they may fail their research project due to lack of help. Majority of the participants agreed that help from the lecturers and friends in research give emotional support for their research activities, this will improve students self-efficacy and reduce research anxiety. This indicates that direction from supervisors is a good panacea to reducing anxiety.

Research writing involves statistical analysis, especially quantitative research, 
and statistic is perceived as very difficult among education students, this causes much anxiety when writing a research report. Awujo and Agbakwuru (2013) investigated research anxiety among education undergraduates in the University of Port Harcourt in a survey study with a sample of 500 students drawn from a population of 1467 final year education undergraduates. The results indicated that research supervision, weak computational ability and instruction contribute significantly to research anxiety.

Research writing makes students experience research anxiety in courses of research methodology (Onwuegbuzie in Ali, 2016). The researchers are in agreement with this assertion because the introduction of research methodology and statistics as post graduate students ignited anxiety in the minds of the researchers. Regrettably, research methods/basic statistics and research project in Education are the most dreaded courses among graduate students (Awujo \& Agbakwuru, 2013). The mere mention or thought of these courses send shivers down the spine of many students. Awujo \& Agbakwuru (2013) noted that this situation is very worrisome when one recalls that anxiety is an enemy of concentration and mental activity. This situation can disorganize the individual and deny one the ability to confront ones' situation realistically.

Awujo \& Agbakwuru (2013) enumerated some factors that trigger research anxiety among students as follows;

- Poor teaching method by some lecturers who teach the course.

- Non/inadequate motivation of students.

- Poor arrangement of teaching material/ideas by some lecturers.

- Inadequate knowledge of the subject matter by some lecturers leading to cheating or confusion of the already confused students.

- Indifferent attitude of some lecturers towards their supervisees' work which is noticeable through excessive delay in reading what the supervisees have written without any reasonable excuse, lack of attention in reading the work, as well as unwillingness/lack of interest in explaining to the supervisees what they are expected to do to improve the quality of the research.

- Irrational belief of some students that research methods/basic statistic and research project in education are difficult courses.

- Lack of commitment to studies by some students.

- Poor computational ability of some students leading to their experience of difficulty in coping with the little statistical content/aspect of both research methods/basic statistic and research project/thesis/dissertation in education.

- Lack of research culture in Nigeria.

The catalogue of problems associated with research writing anxiety among students formed the background for the study.

\section{Statement of Problem}

Anxiety in writing a research report is not new among graduate students in institutions of higher learning. This has caused much concern among students, 
lecturers and school management. The number of students admitted for graduate studies does not match the number that graduate at the stipulated time for graduation as most students abandon their studies after completing course work due to anxiety in writing a research report. Most graduate students cannot complete their studies on record time due to anxiety in writing a research report, spending unnecessary number of years to accomplish this task. Others resort to copying research reports from sister institutions, yet others hire vendors to do the job for them.

Looking at these desperate measures taken by graduate students in a bid to meet the requirement for graduation is worrisome, one begin to wonder the quality of graduates institutions turn into the society. The graduate students in faculties of education are feeders to all tiers of education on graduation, they are the future teachers and lecturers, and if what is described above is what obtains it is obvious that we are heading for a doom as square pegs will be found in round holes in our educational institutions. The issue now is what can a lecturer whose research work was written by another offer? Can a lecturer who copied someone else's work deliver on the job? These and other mind bugging questions triggered the interest of the researchers in investigating library anxiety, supervisor's indifferent attitude and statistic anxiety as the variables to investigate the topic Anxiety in Writing Research Report among Graduate Students in Faculty of Education in Ignatius Ajuru University of Education, Port Harcourt, Rivers State. This is the problem of the study.

\section{Purpose of the Study}

The purpose of this study is to investigate Anxiety in Writing Research Report among Graduate Students in Faculty of Education in Ignatius Ajuru University of Education (IAUE) Port Harcourt, Rivers State. The Specific objectives of the study include;

1) To determine whether fear of library use induces anxiety in writing research report among male and female graduate students in IAUE faculty of education.

2) To investigate whether supervisor's indifferent attitude induces anxiety in writing research report among male and female graduate students in IAUE faculty of education.

3) To ascertain if fear of Statistics induces anxiety in writing research report among male and female graduate students in IAUE faculty of education.

\section{Research Questions}

1) To what extent do fear of library use induces anxiety in writing research report among male and female graduate students in IAUE faculty of education?

2) What is the extent to which supervisors' indifferent attitude induces anxiety in writing research report among male and female graduate students in IAUE faculty of education? 
3) What is the extent to which fear of statistics induces anxiety in writing research report among male and female graduate students in IAUAE faculty of education?

\section{Hypotheses}

The following corresponding null hypotheses were postulated and tested at 0.05 level of significance;

1) Fear of library use does not significantly induce anxiety in writing research report among male and female graduate students in IAUE faculty of education.

2) Supervisors' indifferent attitude does not significantly induce anxiety in writing research report among male and female graduate students in IAUE faculty of education.

3) Fear of statistics does not significantly induce anxiety in writing research report among male and female graduate students in IAUE faculty of education.

\section{Methodology}

The descriptive survey design was adopted for the study. This study enables the researchers to collect data from a large sample drawn from a given population and describes certain features of the sample as they are at the time of the study and which are of interest to the researchers without manipulating any independent variable.

The population of the study consist of $392 \mathrm{MED}$ and $\mathrm{PhD}$ students admitted into the 5 departments in the faculty of education of Ignatius Ajuru University of Education (IAUE) for 2017/2018 academic session. A breakdown shows, 37 MED and $15 \mathrm{PhD}$ from curriculum studies, $27 \mathrm{MED}$ and $18 \mathrm{PhD}$ from Educational foundation, $25 \mathrm{MED}$ and $55 \mathrm{PhD}$ from Guidance and counselling, 99 MED and $80 \mathrm{PhD}$ from Educational management and $32 \mathrm{MED}$ and $4 \mathrm{PhD}$ from Primary education studies (Source: Data obtained from programme coordinator of IAUE faculty of education).

The Census sampling method which involves studying the entire population was adopted for the study because the number of students involved was not much (392). With the use of census sampling, the problem of generalization of findings from a sample of individuals studied directly to the population is completely avoided because census sampling studies every member of the entire population directly (Kpolovie, 2012).

The instrument used for data collection was developed by the researchers and named "Research Writing Anxiety Rating Scale" (RWARS). The instrument was in three (3) sections accompanied by a transmittal letter that specifies the essence of the study.

Section $\mathrm{A}$ is the personal data section indicating sex and type of programme engaged in, while section B consist of fifteen self-report items revealing different sources of anxiety as it affects the individual concerned, 5 questions each on fear of library use, indifferent attitude of supervisors and fear of statistics. The Items were on a four-point scale of Strongly Agree $(\mathrm{SA})=4$, Agree $(\mathrm{A})=3$, Disagree 
$(D)=2$, Strongly Disagree $(S D)=1$. The items on the scale give a minimum of 15 points and a maximum of 60 points. A criterion mean was set to answer the research questions, the mean was obtained from the scores on the scale as follows, $4+3+2+1=10,10 / 4=2.5$, thus a response of 2.5 and below connotes low level of research writing anxiety, 2.6 to 3.0 moderate anxiety while 3.1 and above connotes high level of research anxiety. The raw scores obtained from this instrument were subjected to mean and standard deviation scores which were eventually used for parametric statistical operations for purpose of drawing inferences about the population of the study.

Face and content validity of the instrument was established by experts in measurement and evaluation and guidance and counselling while the reliability of the instrument was determined through a test-retest approach for a measure of stability at four weeks' interval. A simple random sampling method was used to draw a sample of twenty MED and PhD students from the Rivers State University, Nkpolu, Port Harcourt who are not part of the study. The subjects were required to rate the extent to which each of the items is applicable to them by responding sincerely to it. It was done and retrieved the same day. After an interval of four weeks, the same instrument was re-administered on the same sample. In order to control memory effects of the test, which is a known weakness of the test retest measure, the items of the test were re-ordered to disguise its former pattern. Re-ordering the items implies repeating the same items as they appear in the first test but changing position or numbers during the second administration. The initial scores and the retest scores of the sample were correlated using Pearson product moment correlation test to ascertain its reliability and it yielded a co-efficient value of $\mathrm{r} 0.83$ which was accepted to be high for utilization. The Direct Delivery Method (DDM) which implies administering the questionnaire personally or through an assistant was used for purpose of explaining further, terms that may not be clear to the respondents. The different course representatives in the various departments in the faculty of Education of IAUE were trained as research assistants; they helped the researchers to coordinate the administration of the instrument. With the involvement of the course representative's high retrieval rate was achieved for the study although there was dearth of 9 instruments, 383 were successfully retrieved. The research questions were answered with the set criterion mean of 2.5 while the three (3) null hypotheses were tested at 0.05 level of significance with the Z-test statistic.

\section{Results}

Gleaned field data was analyzed and used to answer the research questions and test hypotheses, the results are shown on relevant tables.

Research Question 1: To what extent do fear of library use induces anxiety in writing research report among male and female graduate students in IAUE faculty of education?

Table 1 shows that fear of library use induces moderate anxiety among graduate 
Table 1. Mean response of male and female graduate students on fear of library use.

\begin{tabular}{|c|c|c|c|c|c|c|c|c|c|c|}
\hline $\mathrm{s} / \mathrm{n}$ & Items & $\mathrm{SA}=4$ & $A=3$ & $\mathrm{D}=2$ & $\mathrm{SD}=1$ & Total & $\sum f x^{2}$ & Mean & $\begin{array}{l}\text { Criterion } \\
\text { mean }\end{array}$ & Remark \\
\hline 1 & $\begin{array}{l}\text { Searching for materials in the } \\
\text { library gives me so much stress }\end{array}$ & $\begin{array}{c}\mathrm{M}=60(240) \\
\mathrm{F}=70(280)\end{array}$ & $\begin{array}{l}38(114) \\
98(294)\end{array}$ & $\begin{array}{l}31(62) \\
65(130)\end{array}$ & $\begin{array}{c}9(9) \\
12(12)\end{array}$ & $\begin{array}{c}M=138 \\
F=245\end{array}$ & $\begin{array}{l}425 \\
716\end{array}$ & $\begin{array}{l}3.1 \\
2.9\end{array}$ & 2.5 & $\begin{array}{l}\text { High anxiety } \\
\text { Moderate } \\
\text { Anxiety }\end{array}$ \\
\hline 2 & $\begin{array}{l}\text { The indifferent attitude of library } \\
\text { staff puts me off the library }\end{array}$ & $\begin{array}{l}M=45(180) \\
F=85(340)\end{array}$ & $\begin{array}{l}32(96) \\
92(276)\end{array}$ & $\begin{array}{l}38(76) \\
38(76)\end{array}$ & $\begin{array}{l}23(23) \\
30(30)\end{array}$ & Do & $\begin{array}{l}375 \\
722\end{array}$ & $\begin{array}{l}2.7 \\
2.9\end{array}$ & Do & $\begin{array}{l}\text { Moderate } \\
\text { Anxiety }\end{array}$ \\
\hline 3 & $\begin{array}{l}\text { The rules and regulations in the } \\
\text { library are too rigid }\end{array}$ & $\begin{array}{c}M=34(136) \\
F=73(372)\end{array}$ & $\begin{array}{l}42(126) \\
52(156)\end{array}$ & $\begin{array}{l}32(64) \\
41(82)\end{array}$ & $\begin{array}{l}30(30) \\
59(69)\end{array}$ & Do & $\begin{array}{l}356 \\
679\end{array}$ & $\begin{array}{l}2.6 \\
2.7\end{array}$ & Do & $\begin{array}{l}\text { Moderate } \\
\text { Anxiety }\end{array}$ \\
\hline 4 & $\begin{array}{l}\text { The thought of going to the } \\
\text { library makes me sick }\end{array}$ & $\begin{aligned} M & =42(168) \\
F & =92(368)\end{aligned}$ & $\begin{array}{l}39(117) \\
85(255)\end{array}$ & $\begin{array}{l}30(60) \\
30(60)\end{array}$ & $\begin{array}{l}27(27) \\
38(38)\end{array}$ & Do & $\begin{array}{l}372 \\
721\end{array}$ & $\begin{array}{l}2.7 \\
2.9\end{array}$ & Do & $\begin{array}{l}\text { Moderate } \\
\text { Anxiety }\end{array}$ \\
\hline 5 & $\begin{array}{l}\text { The inscription "silence" placed at } \\
\text { the library is worrisome, can't do } \\
\text { without talking }\end{array}$ & $\begin{array}{l}M=62(248) \\
F=102(408)\end{array}$ & $\begin{array}{l}32(96) \\
82(246)\end{array}$ & $\begin{array}{l}30(60) \\
41(82)\end{array}$ & $\begin{array}{l}14(14) \\
20(20)\end{array}$ & Do & $\begin{array}{l}418 \\
756\end{array}$ & $\begin{array}{l}3.0 \\
3.1\end{array}$ & Do & $\begin{array}{c}\text { Moderate } \\
\text { Anxiety } \\
\text { High Anxiety }\end{array}$ \\
\hline & Grand Mean & & & & & & & $\begin{aligned} \mathrm{M} & =2.8 \\
\mathrm{~F} & =2.9\end{aligned}$ & Do & $\begin{array}{l}\text { Moderate } \\
\text { Anxiety }\end{array}$ \\
\hline
\end{tabular}

Note: $\mathrm{M}$ in the cells represents male while F represents Female.

students on all the items except items 1 and 5 where high anxiety level was exhibited by male students on item 1 and the females on item 5 . On the whole male students had a grand mean of 2.8 and the females had 2.9. Overall grand mean for both groups is 2.9. The answer to research question 2 therefore is, fear of library use induces anxiety among male and female graduate students to a moderate extent.

Research Question 2: What is the extent to which supervisors' indifferent attitude induces anxiety in writing research report among male and female graduate students in IAUE faculty of education?

Table 2 indicates moderate anxiety on supervisors' indifferent attitude among male and female graduate students on all the items except on items 3,4 and 5 where male and female students indicated varied levels of anxiety. The mean for male students is 2.9 and females 2.9 , the grand mean of both groups is 2.9 this shows moderate anxiety on supervisors' indifferent attitude generally among male and female graduate students. The answer to research question 2 therefore is, supervisors' indifferent attitude induces anxiety among male and female graduate students in writing research report to a moderate extent.

Research Question 3: What is the extent to which fear of statistics induces anxiety in writing research report among male and female graduate students in IAUAE faculty of education?

Table 3 shows low anxiety on fear of statistic on the part of male students on all the items, while female students exhibited high anxiety level on items 3, 4, 5 and moderate anxiety on items 1 and 2. Male students had a grand mean of 2.1 and females 3.3 this indicates that girls had a high anxiety level with regards to statistics while boys had a low anxiety for statistics. The answer to research question 3 therefore is: fear of statistics induces anxiety in female students than in 
Table 2. Mean responses of male and female graduate students on Indifferent attitude of supervisors

\begin{tabular}{|c|c|c|c|c|c|c|c|c|c|c|}
\hline $\mathrm{s} / \mathrm{n}$ & Items & $\mathrm{SA}=4$ & $A=3$ & $\mathrm{D}=2$ & $\mathrm{SD}=1$ & Total & $\sum f x^{2}$ & Mean & $\begin{array}{l}\text { Criterion } \\
\text { mean }\end{array}$ & Remark \\
\hline 1 & $\begin{array}{l}\text { My supervisor's lack of interest in } \\
\text { reading my work puts me off }\end{array}$ & $\begin{array}{l}\mathrm{M}=39(156) \\
\mathrm{F}=110(440)\end{array}$ & $\begin{array}{l}50(150) \\
63(189)\end{array}$ & $\begin{array}{l}25(50) \\
32(64)\end{array}$ & $\begin{array}{l}24(24) \\
(40)\end{array}$ & $\begin{array}{l}138 \\
245 \\
383\end{array}$ & $\begin{array}{l}380 \\
733\end{array}$ & $\begin{array}{l}2.8 \\
3.0\end{array}$ & 2.5 & $\begin{array}{l}\text { Moderate } \\
\text { Anxiety }\end{array}$ \\
\hline 2 & $\begin{array}{l}\text { Continuous cancellation of my } \\
\text { work without correction gives me } \\
\text { concern }\end{array}$ & $\begin{array}{c}\mathrm{M}=52(208) \\
\mathrm{F}=98\end{array}$ & $\begin{array}{l}49(147) \\
56(168)\end{array}$ & $\begin{array}{l}22(44) \\
49(98)\end{array}$ & $\begin{array}{l}15(15) \\
42(42)\end{array}$ & Do & $\begin{array}{l}414 \\
700\end{array}$ & $\begin{array}{l}3.0 \\
2.9\end{array}$ & Do & $\begin{array}{l}\text { Moderate } \\
\text { Anxiety }\end{array}$ \\
\hline 3 & $\begin{array}{l}\text { Unwillingness to explain what is } \\
\text { expected to improve the quality } \\
\text { of my work is discouraging }\end{array}$ & $\begin{array}{c}\mathrm{M}=61(244) \\
\mathrm{F}=92(368)\end{array}$ & $\begin{array}{l}48(144) \\
81(243)\end{array}$ & $\begin{array}{l}20(40) \\
48(96)\end{array}$ & $\begin{array}{c}9(9) \\
24(24)\end{array}$ & Do & $\begin{array}{l}437 \\
731\end{array}$ & $\begin{array}{l}3.1 \\
3.0\end{array}$ & Do & $\begin{array}{l}\text { High Anxiety } \\
\text { Moderate } \\
\text { Anxiety }\end{array}$ \\
\hline 4 & $\begin{array}{l}\text { I can't face my supervisor's } \\
\text { unfriendly disposition }\end{array}$ & $\begin{array}{l}M=42(168) \\
F=102(408)\end{array}$ & $\begin{array}{l}52(156) \\
88(264)\end{array}$ & $\begin{array}{l}38(76) \\
45(90)\end{array}$ & $\begin{array}{c}6(6) \\
10(10)\end{array}$ & Do & $\begin{array}{l}406 \\
772\end{array}$ & $\begin{array}{l}2.9 \\
3.2\end{array}$ & Do & $\begin{array}{l}\text { Moderate } \\
\text { Anxiety High } \\
\text { Anxiety }\end{array}$ \\
\hline 5 & $\begin{array}{l}\text { Delay in reading my work puts } \\
\text { me off }\end{array}$ & $\begin{array}{c}M=59(236) \\
F=52(208)\end{array}$ & $\begin{array}{l}31(93) \\
59(177)\end{array}$ & $\begin{array}{c}30(60) \\
80(160)\end{array}$ & $\begin{array}{l}18(18) \\
54(54)\end{array}$ & Do & $\begin{array}{l}407 \\
599\end{array}$ & $\begin{array}{l}2.9 \\
2.4\end{array}$ & Do & $\begin{array}{l}\text { Moderate } \\
\text { Anxiety } \\
\text { Low Anxiety }\end{array}$ \\
\hline & Grand Mean & & & & & & & $\begin{aligned} \mathrm{M} & =2.9 \\
\mathrm{~F} & =2.9\end{aligned}$ & Do & $\begin{array}{l}\text { Moderate } \\
\text { Anxiety }\end{array}$ \\
\hline
\end{tabular}

Table 3. Mean responses of male and female graduate students on fear of statistics.

\begin{tabular}{|c|c|c|c|c|c|c|c|c|c|c|}
\hline$s / n$ & Items & $\mathrm{SA}=4$ & $A=3$ & $\mathrm{D}=2$ & $\mathrm{SD}=1$ & Total & $\sum f x^{2}$ & Mean & $\begin{array}{l}\text { Criterion } \\
\text { Mean }\end{array}$ & Remark \\
\hline 1 & $\begin{array}{c}\text { I am scared of statistical } \\
\text { analysis }\end{array}$ & $\begin{array}{l}\mathrm{M}=22(88) \\
\mathrm{F}=80(320)\end{array}$ & $\begin{array}{c}25(75) \\
95(285)\end{array}$ & $\begin{array}{l}50(100) \\
31(62)\end{array}$ & $\begin{array}{l}41(41) \\
39(39)\end{array}$ & $\begin{array}{l}138 \\
245\end{array}$ & $\begin{array}{l}304 \\
706\end{array}$ & $\begin{array}{l}2.2 \\
2.9\end{array}$ & 2.5 & $\begin{array}{c}\text { Low Anxiety } \\
\text { Moderate } \\
\text { Anxiety }\end{array}$ \\
\hline 2 & $\begin{array}{l}\text { I cannot organize data } \\
\text { gathered } \\
\text { from the field }\end{array}$ & $\begin{array}{l}M=11(44) \\
F=73(312)\end{array}$ & $\begin{array}{l}18(54) \\
92(276)\end{array}$ & $\begin{array}{l}63(126) \\
50(100)\end{array}$ & $\begin{array}{l}57(57) \\
25(25)\end{array}$ & DO & $\begin{array}{l}281 \\
713\end{array}$ & $\begin{array}{l}2.0 \\
2.9\end{array}$ & Do & $\begin{array}{c}\text { Low Anxiety } \\
\text { Moderate } \\
\text { Anxiety }\end{array}$ \\
\hline 3 & $\begin{array}{l}\text { I cannot stand the rigors of } \\
\text { calculation }\end{array}$ & $\begin{array}{c}\mathrm{M}=20(80) \\
\mathrm{F}=170(680)\end{array}$ & $\begin{array}{l}25(75) \\
42(126)\end{array}$ & $\begin{array}{c}55(110) \\
18(36)\end{array}$ & $\begin{array}{l}38(38) \\
15(15)\end{array}$ & Do & $\begin{array}{l}303 \\
857\end{array}$ & $\begin{array}{l}2.2 \\
3.5\end{array}$ & Do & $\begin{array}{l}\text { Low Anxiety } \\
\text { High Anxiety }\end{array}$ \\
\hline 4 & I am always scared of figures & $\begin{array}{c}M=18(72) \\
F=168(672)\end{array}$ & $\begin{array}{l}28(84) \\
50(150)\end{array}$ & $\begin{array}{l}52(104) \\
19(38)\end{array}$ & $\begin{array}{c}40(40) \\
8(8)\end{array}$ & Do & $\begin{array}{l}300 \\
868\end{array}$ & $\begin{array}{l}2.2 \\
3.4\end{array}$ & Do & $\begin{array}{l}\text { Low Anxiety } \\
\text { High Anxiety }\end{array}$ \\
\hline 5 & $\begin{array}{l}\text { I am jittery of computation in } \\
\text { research writing }\end{array}$ & $\begin{array}{c}\mathrm{M}=9(36) \\
\mathrm{F}=153(612)\end{array}$ & $\begin{array}{l}12(36) \\
82(246)\end{array}$ & $\begin{array}{c}58(116) \\
8(16)\end{array}$ & $\begin{array}{l}79(79) \\
2(2)\end{array}$ & Do & $\begin{array}{l}267 \\
876\end{array}$ & $\begin{array}{l}1.9 \\
3.6\end{array}$ & Do & $\begin{array}{l}\text { Low Anxiety } \\
\text { High Anxiety }\end{array}$ \\
\hline & Grand Mean & & & & & & & $\begin{aligned} \mathrm{M} & =2.1 \\
\mathrm{~F} & =3.3\end{aligned}$ & Do & $\begin{array}{c}\text { Low \& } \\
\text { High Anxiety }\end{array}$ \\
\hline
\end{tabular}

male students to a large extent.

Hypothesis 1: Fear of library use does not significantly induce anxiety in writing research report among male and female graduate students in IAUE faculty of education.

Table 4 shows that the calculated Z-test value of 0.1 is lower than the critical value of Z-test, which is 1.960 with a degree of freedom of 381 at 0.05 level of significance, on this basis the null hypothesis was accepted. The acceptance of the null hypothesis indicates that fear of library use does not significantly induce 
anxiety in writing research report among male and female graduate students in IAUE faculty of education.

Hypothesis 2: Supervisors' indifferent attitude does not significantly induce anxiety in writing research report among male and female graduate students in IAUE faculty of education.

Table 5 indicates a calculated Z-test value of 0 , table value of Z-test at 1.960 , this was not found to be significant at 0.05 level $(P>0.05)$ with a degree of freedom of 381. This calls for the acceptance of Ho2, the acceptance of Ho2 indicates that supervisors' indifferent attitude does not significantly induce anxiety in writing research report among male and female graduate students in IAUE faculty of education.

Hypothesis 3: Fear of statistics does not significantly induce anxiety in writing research report among male and female graduate students in IAUE faculty of education.

Table 6 shows that the calculated Z-test value of 14 was significant at 0.05 level with a degree of freedom of 381 and Z-test critical value of 1.960 hence, the null hypothesis was rejected. The rejection of the null hypothesis means that fear of statistic induces anxiety among male and female graduate students significantly in writing research report in IAUE faculty of education.

Table 4. Result of Z-test showing male and female graduate students fear of library use.

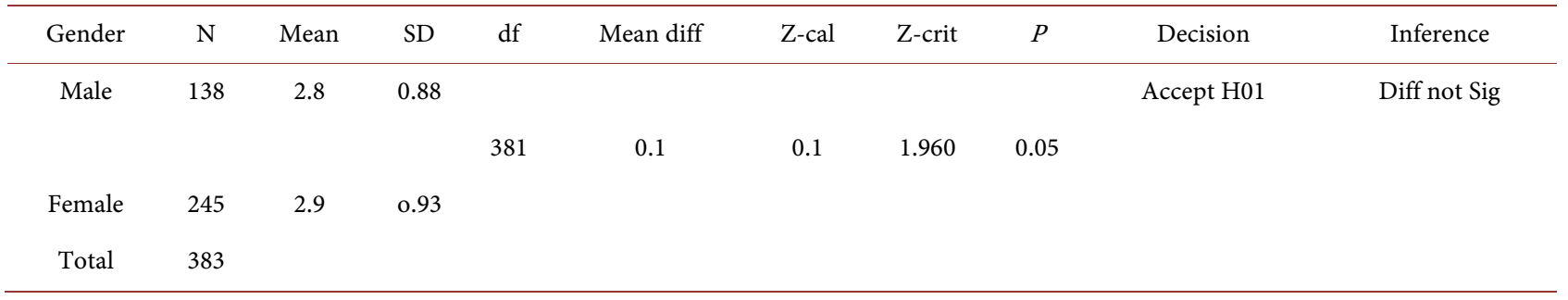

Table 5. Results of Z-test showing male and female graduate students on supervisor's indifferent attitude.

\begin{tabular}{|c|c|c|c|c|c|c|c|c|c|c|}
\hline Gender & $\mathrm{N}$ & Mean & SD & df & Mean diff & Z-cal & Z-crit & $P$ & Decision & Inference \\
\hline Male & 138 & 2.9 & 0.91 & & & & & & Accept Ho2 & Diff not Sig \\
\hline Female & 245 & 2.9 & 0.93 & & & & & & & \\
\hline Total & 383 & & & & & & & & & \\
\hline
\end{tabular}

Table 6. Results of Z-test on male and male graduate students fear of statistics.

\begin{tabular}{|c|c|c|c|c|c|c|c|c|c|c|}
\hline Gender & $\mathrm{N}$ & Mean & $\mathrm{SD}$ & $\mathrm{df}$ & Mean diff & Z-cal & Z-crit & $P$ & Decision & Inference \\
\hline \multirow[t]{2}{*}{ Male } & 138 & 2.1 & 0.35 & & & & & & Reject Ho3 & $\begin{array}{l}\text { Difference } \\
\text { significant }\end{array}$ \\
\hline & & & & 381 & 1.2 & 14 & 1.960 & 0.05 & & \\
\hline Female & 245 & 3.3 & 1.2 & & & & & & & \\
\hline Total & 383 & & & & & & & & & \\
\hline
\end{tabular}




\section{Discussion of Findings}

\section{Library use and Anxiety in Research Writing}

The information in Table 1 and Table 4 explains the results of the first finding; mean scores obtained in Table 1 that is, 2.8 for males and 2.9 for females indicates that fear of library use induces moderate anxiety among male and female graduate students in writing research report. When this mean scores were further subjected to the Z-test statistics, the data provided in Table 4 that tested the null hypothesis 1 revealed that fear of library use does not induce anxiety in writing research report significantly among male and female graduate students in faculties of education. The results of this study are in consonance with the findings of Lu and Adkins (2018) who investigated library anxiety among 15 international graduate students in the United State. Finding from the pilot study shows that mechanical barriers were the smallest sources of library anxiety. No significant gender or disciplinary difference was found in terms of library anxiety among international students. This result is not surprising but expected because the role of the library is to support the students' information needs by providing them relevant resources and services. The result of this study also agrees with the findings of McPherson (2015) who investigated library anxiety among University students in a survey. The study specifically sought to determine if there were any indicators of the presence of library anxiety among a sample of 150 undergraduate students in the faculties of humanities and education at the University of West Indies, Mona campus. Results indicated the presence of library anxiety of short term duration among the students due to both personal and institutional factors from the result of this finding and the empirical support evidences it can be inferred that good use of library will propel research writing and dispel research anxiety.

\section{Supervisors' Indifferent Attitude to Research Supervision and Anxiety in Writing Research Report}

The results in Table 2 and Table 5 provided the data needed for discussion of the second finding. Table 2 shows that supervisors' indifferent attitude contributes to research anxiety moderately judging from the mean scores obtained that is male 2.9, females 2.9. Further subjection of these mean scores to Z-test statistics shows data in Table 5 that tested the null hypothesis, it shows that supervisors' indifferent attitude does not induce anxiety in writing research report among graduate students. This result is surprising not expected because most often supervisors delay reading supervisees work without any reasonable excuse, some do not even take patience to explain to the supervisees what they are expected to do to improve the quality of their research, some even shout and bully their supervisees instead of encouraging and giving them all the needed support, this kind of attitude is bound to induce research anxiety. The results of this study is however in tune with the findings of Maharajan, Rajiah, Tam, Chaw, Ang and young (2017) who investigated pharmacy students anxiety towards research during their undergraduate degree and how to reduce it in a cross sectional 
study. Results revealed that $91.4 \%$ of the students felt that they were doing very badly during their data analysis or they may fail their research project due to lack of help. Majority of the students agreed that help from the supervisor and friends in research give emotional support for their research activities that will improve students' self-efficacy and reduce research anxiety. However, the work of Awujo and Agbakwuru (2013) shows disparity with the findings of this study, they discovered that supervisors' indifferent attitude contributes to research anxiety. The difference in result could be as a result of the level of students involved, the former dealt with undergraduate students while the latter graduate students. The inference here is that good working relationship between supervisor and supervisee will go a long way to reducing research anxiety.

\section{Fear of Statistics and Anxiety in Writing Research Report}

The third finding shown in Table 3 and Table 6 shows that fear of statistics induces anxiety immensely in writing research report among female graduate students judging from their mean scores of 2.1 for males and 3.3 for females. This was found to be significant when the mean scores were subjected to Z-test statistics. The finding was not surprising but expected because most female students in non-mathematical departments are always scared of computation. Research writing in faculties of education requires quantitative research writing in most cases which favours statistics. This study is in agreement with the findings of Awujo and Agbakwuru (2013) who studied research anxiety among final year education undergraduates in University of Port Harcourt and found out that research anxiety is pervasive among final year undergraduates and that weak computational ability of students contributes immensely to research anxiety. That of Collins in Onwuegbuzie (2004) also agrees with this present study, they discovered that students with poor reading ability tend to experience higher levels of statistics anxiety. The study also corroborates the study conducted by Chew and Dillon (2014) who discovered empirical evidence that suggests that, students in non-mathematical courses like Education, Arts, Social sciences and so on regards statistics courses as very scary and difficult in their degree programmes. From the empirical evidences agreeing with this finding it can be inferred that students with good computational ability will not have any research anxiety for research writing.

\section{Conclusion/Recommendation}

From the findings of this study it was concluded that, fear of library use and indifferent attitude of supervisors induce moderate anxiety on both male and female graduate students in IAUE faculty of education in cause of writing research report and the results on these two variables were not found to be significant in hypotheses testing. Fear of statistics induces high level of anxiety on female students and low level of anxiety on male students and the result was found to be significant. Based on these findings it was recommended that,

1) Library staff in IAUE should be given a proper orientation on how to deal 
with students in a polite manner. Courtesy should be emphasized in all their dealings with users of the library. Defaulting staff should be penalized. Students suggest that introduction to library use should be a major course at the post graduate level.

2) Supervisors who turn out graduate students on record time should be given good incentives in cash or kind. Students should be made to assess them on graduation based on the level of input made on their research work and 30\% of promotion assessment should be based on students' recommendation. Students suggest that supervisors who bully students should be shown the way out as this is a major obstacle to completion of research report.

3) Lecturers with good knowledge of statistic and good teaching approach should be given statistics and research methodology to teach at the graduate level. This recommendation is in line with that of the students.

\section{Conflicts of Interest}

The authors declare no conflicts of interest regarding the publication of this paper.

\section{References}

Agbakwuru, C. (2010). Inculcating and Promoting the Interest of Research for Research in Nigerian Children. National Educational Association Journal, 32, 90-97.

Akinade, E. A. (2001). Modern Concise Dictionary of Psychology. Lagos: Pumark Nigeria Limited.

Ali, M. (2016). Research Anxiety among Turkish Gradates ELT Students. Current Issues in Education, 19, 30-38.

Awujo, C. G., \& Agbakwuru, C. (2013). Research Anxiety among Education Undergraduates. African Journal of Higher Education Studies and Development, 1, 220-227.

Chew, P. K. H., \& Dillion, D. B. (2014). Statistics Anxiety Update. Refining the Construct and Recommendations for a New Research Agenda. Perspective on Psychological Science, 9, 196-208. https://doi.org/10.1177/1745691613518077

Kpolovie, P. J. (2012). Statistical Technique for Advance Research. New Owerri: Spring Field Publishers Ltd.

Lu, Y., \& Adkins, D. (2018). Library Anxiety among International Graduate Student on Information Science and Learning Technology. Columbia, MO: University of Missouri.

Maharajan, M. K., Rajaih, K., Tam, A. M., Chaw, S. I., Ang, M. J., \& Young, M. W. (2017). Pharmacy Students Anxiety towards Research during Their Undergraduate Degree, How to Reduce It? PLoS ONE, 12, e0176095.

https://doi.org/10.1371/journal.pone.0176095

McPherson, M. A. (2015). Library Anxiety among University Students: A Survey. Sage Journals, IFLA Journal, 41, 317-325.

https://journals.sagepub.com/doi/abs/10.1177/0340035215603993

https://doi.org/10.1177/0340035215603993

Nwankwo, O. C. (2013). A Practical Guide to Research Writing for Students of Research Enterprise (3rd ed.). Port Harcourt: University of Port Harcourt Press.

Okoroma, N. S. (2013). Say NO to Carry Over of Courses the Strategies. Port Harcourt: 
Anoks Publishers.

Onwuegbuzie, A. J. (1997). Statistics Anxiety among African American Graduate Students an Effective Filter. Journal of Black Psychology, 25, 189-209. https://doi.org/10.1177/0095798499025002004

Onwuegbuzie, A. J. (2004). Academic Procrastination and Statistics Anxiety. Assessment and Evaluation in Higher Education, 29, 3-19. https://doi.org/10.1080/0260293042000160384

Onwuegbuzie, A. J. (2013). Development and Score Validities of the Research Anxiety Rating Scale. International Journal of Research in Education Methodology, 4, 503-515. 